the intention of doing a hysterectomy. In 1842 Charles Clay had likewise made a similar mistake in diagnosis, but he abandoned the operation when he discovered the tumour was uterine.

The first deliberate hystero-myomectomy was that performed in June, 1846, by John Bellinger, of South Carolina, U.S.A. The patient, a coloured woman, died upon the fifth day from peritonitis. The first successful hysterectomy was performed by Walter Burnham, of Lowell, Massachusetts, on June 26th, 1853. This was not a deliberate operation, as Burnham considered the tumour to be ovarian. After the incision was made the patient vomited, forcing the uterus, the fibroid, and associated ovarian tumours out of the wound, and as Burnham was unable to replace the mass he did a supravaginal removal of the uterus, with ligation of the lateral arteries. A left ovarian tumour was removed and a right ovarian tumour also incised. The ligation of the ovarian and uterine arteries in the broad ligaments is similar to that of the modern operation. Burnham continued to do the operation from time to time, performing altogether 15 operations, but only three of his patients recovered.

The first deliberate and successful hysterectomy for fibroid tumour was performed by G. Kimball, of Lowell, Massachusetts, on Sept. 1st, 1853. Kimball had a clear concept of the diagnosis, and in his writings advocated the operation. Previons to 1856 Kimball operated four times for fibroid tumours of the uterus, with but one recovery. The successful operation of $\mathrm{E}$. Koeberlé was not performed until April 20th, 1863. The first successful abdominal myomectomy is apparently that of W. L. Atlee, of Pennsylvania, performed on August 28th, 1844. This was not a deliberate myomectomy as the tumour was supposed to be ovarian, but the ovaries were found to be normal at the necropsy three years later.

The honour of having performed the first deliberate hysterectomies for fibroid tumour seems to belong to the following surgeons in the order named:-Bellinger, Kimball, Burnham, Clay, and Koeberlé. For a fuller discussion of the subject and a careful tabulated bibliography of the early operations for fibroid tumours, reference may be made to the article by Noble in the American Tournal of Obstetries, Vol. XL., No. 2, 1899.--I am, Sir, yours faithfully,

Philadelphia, U.S.A., Dec.18th, 1911。 W. WAYNE BABCOCK.

\section{THE PRESCRIPTION OF TUBERCULIN.}

\section{To the Editor of THE LANCET.}

SrR,-I can see nothing in Mr. Gamble's letter to modify my opinion. Whatever terms are used, and however explicit the physician may be to indicate his intentions, one comes back to the fact that he is ordering a specific fluid, and the dilution of that fluid must be calculated in measures. In my last communication I referred to Koch's bacillary emulsion, because at the time I was making dilutions of that fluid, but it applies with even greater force to Koch's new tubercalin T.R. 1 c.c. of this fluid contains the active bacterial matter of 10 milligrammes of tubercle bacilli, which represents 2 milligrammes of solid substance. I have seen the dose of T.R. indicated in decimals or fractions of a c.c. of that fluid, in fractions of a milligramme of tubercle bacilli, and in fractions of a milligramme of solid substance. Therefore it would be far better, and would avoid any possibility of confusion if it were always ordered in decimals or fractions of a c.c. of the original fluid. Personally, I prefer to work in decimals. I am, Sir, yours faithfully,

London, Dec. 19th, 1911. P. W. SQUIRE.

\section{"GREEN" TEA.}

\section{To the Editor of THW LANCET.}

Sir,--I have had a good deal to do with China tea, and therefore $I$ am much interested in your annotation on p. 1786 of THE LANCET of Dec. 23rd. Your correspondent says that formerly Prussian blue was used for colouring the leaf in "green" tea. I should be very much obliged if you would ask him to supplement his interesting letter by stating what evidence there is of the former use of this pigment. The statement was freely made in this country some 35 or more years ago, and to it was largely due the disuse of green tea and the ruin of the trade in green tea in this country; but I do not think it was made on any sure basis of faot. For all that it may have been true, and I should be glad to know if your correspondent has any evidence to offer.

I am, Sir, yours faithfully,

Duchess-street, W., Dec. 29th, 1911. E. MuIRHEAD LiTtLe.

\section{SPONGE EDUCTION.}

\section{To the Editor of $\mathrm{TH} \mathrm{H}$ L NCET.}

SIR,-In your issue of Nov. 11th, p. 1348, you have an annotation on "Sponge Eduction." This I read with much interest, but would point out that this is by no means a new form of treatment, and I do not think it had its origin in America, as you suggest. In $1889 \mathrm{Mr}$. A. G. Miller, surgeon to the Royal Infirmary, Edinburgh, regularly taught his students the advantages of applying prepared sponge for encouraging the growth of granulations. He termed his system "sponge grafting." His then house surgeon, Mr. Alexander Miles (now surgeon to the Royal Inflrmary, Edinburgh), will doubtless recollect these successful experiments. In 1892 I was consulted by a lady with a large callous ulcer on her leg. She informed me that this had been present for over ten years and had resisted all treatment. Following the method taught by Mr. Miller, I sponge-grafted the leg, and in four months the ulcer had disappeared, leaving a firm cicatrix. I met, my patient in 1908, and she informed me that the leg was in excellent condition and had given no further trouble. In numerous cases I have tried Mr. Miller's so-called "sponge grafting" to encourage growth of granulation tissue and invariably with good results.-I am, Sir, yours faithfully,

DaVID Donald, M.D. Durh., L.R.C.P. \& S. Edin., L.F.P.S. Glasg.

Victoria, British Columbia, Dec. 4th, 1911.

* * In this regard we may mention a letter in The LANCeT of Nov. 25th, 1911 (p. 1516), where the work of Professor D. J. Hamilton is quoted:-ED. L.

\section{THE ACTION OF RADIUM ON MALIGNANT GROWTHS.}

\section{To the Editor of THE LANCET.}

StR,-Many explanations have been advanced as to how radium acts in cases of malignant growths. Some authorities, such as Wickham (Paris) and Finzi (London), maintain-and, I think, with good cause-that radium exercises a selective or specific action on cancer cells, while others, among whom may be mentioned Bashford (director of the Imperial Cancer Research) and Mansell Moullin, refuse to see any such selective action, and state the action of radium is merely that of a powerful caustic. Its action in such a case might be comparable to that of arsenic paste, zinc chloride, potassium bichromate, and other chemical caustics the application of which has occasionally given good results in cancerous growth.

A third theory, propounded by Deane Butcher, is that radium possibly acts as a vaccine, its rays exciting the leucocytes to the production of antibodies. In support of this it might be stated that the opsonic index has been found raised after applications both of $X$ rays and radium.

Dominici, ${ }^{1}$ in an interesting article, shows by means of microscropic sections the gradual retrogression of a case of sarcoma under the influence of radium. Briefly, the sarcoma is converted into a fibroma, which is eventually changed into scar tissue. The changes described are apparently of the same nature as those occurring in the "spontaneous or natural cure of cancer." 2

Dominici, moreover, demonstrates that this fibroma is not made up of the vascular connective tissue which exists between the sarcomatous cells, but is a result of the transformation of the sarcomatous element itself. Briefly, this change, he says, is brought about in the following manner. 1. A metamorphosis of some of the protoplasma of the plasmodial elements as well as the sarcomatous cells into connective tissue fibres. 2. A transformation of the remainder of the protoplasma and of the nuclei of the sarcomatous elements into permanent fibrous tissue cells. 3. The obliteration of the blood-vessels. I have purposely

I Archives Générales de Médecine, Radium Number, July, 1909. 3 Handley: Brit, Med, Jour, March 6th, 1909. 